Матеріали Всеукраїнської науково-практичної конференчії «Актуальні питання діагностики, лікування, рачіональної фармакотерапії, диспансеризачії та реабілітації в практиці сімейного лікаря»

DOI

\title{
РЕЗУЛЬТАТИ ОЦІНКИ ЯКОСТІ ЖИТТЯ ХВОРИХ НА ХРОНІЧНИЙ ПАНКРЕАТИТ ІЗ СУПУТНІМ ОСТЕОДЕФІЦИТОМ
}

○І. В. Семенова, Л. С. Бабінець

ДВНз «Тернопільський державний медичний університет імені І. Я. Горбачевського мОз Украӥни»

Вступ. Оцінка якості життя (ЯЖ) важлива при хронічних захворюваннях, що вимагаютьтривалої терапії, до яких відносяться як хронічний панкреатит (ХП), так і остеодефіцит (ОД). Високе медикосоціальне значення ХП та ОД визначається їх значним внеском у патологію людей соціально активного віку, великими витратами на діагностику і лікування, зниженням ЯЖ і працездатності.

Мета: провести порівняльний аналіз якості життя хворих на ХП залежно від наявності супутнього ОД.

Матеріали та методи дослідження. Проводили оцінку 55 хворих на ХП, яких поділили на дві групи: I (27 хворих на ХП без ОД) і II (28 пацієнтів 3 ХП і ОД). Хворі були зіставні за віком, статтю і перебігом ХП. Оцінку ЯЖ хворих на ХП здійснювали за допомогою загального опитувальника SF-36, що дозволило об'єктивізувати ЯЖ хворих на ХП з ОД та здійснити моніторинг лікування ХП з корекцією ОД. За опитувальником SF-36 оцінили стан фізичного і психологічного здоров'я.

Результати та обговорення. За даними аналізу анкет SF-36 було виявлено достовірне зниження показників усіх шкал, які характеризують як фізичний компонент здоров'я, так і психічний, стосовно групи контролю. Найбільш зниженими виявилися показники, що характеризують фізичний компонент здоров'я $(p<0,05)$. При порівнянні показників ЯЖ хворих на ХП з ОД та без нього між собою (I та II групи) та із групою здорових осіб виявлено, що ОД погіршував ЯЖ хворих, впли- ваючи на всі рівні життєдіяльності: фізичне, емоційне, рольове, психологічне, соціальне функціонування: фізичний компонент здоров'я становив $(52,3 \pm 6,4)$ бали у I групі, $(42,1 \pm 8,3)$ бали - у II групі, що достовірно нижче, ніж у групі здорових осіб $(87,3 \pm 4,6)$ бали $(p<0,05)$. Показники болю та його Вплив на спроможність займатися повсякденною діяльністю, включаючи роботу вдома та за його межами, були зниженими у пацієнтів обох груп у зіставленні з групою здорових $(p<0,05)$. Встановлено, що фізична активність у хворих на ХП із супутнім ОД була значно нижчою від групи контролю $(p<0,05)$. Комплексна оцінка психічного компонента здоров'я показала, що він був достовірно нижчим у пацієнтів II групи, порівняно з I - $(43,0 \pm 3,7)$ бали проти $(75,3 \pm 3,2)$ бали $(p<0,05)$. Тенденцію до зниження психічного здоров'я констатували у хворих обох груп, порівняно із здоровими. Низькі показники свідчать про наявність депресивних, тривожних хвилювань, психічного неблагополуччя у хворих на ХП у поєднанні з ОД.

Висновок. При хронічному панкреатиті, особливо у поєднанні з супутнім остеодефіцитом, було виявлено погіршення показників ЯЖ, порівняно із здоровими. Наявність ОД достовірно погіршувала життєдіяльність, загальне та психічне здоров'я, соціальну активність пацієнтів.

У перспективі подальших досліджень - порівняльна оцінка якості життя даних груп пацієнтів у ході проведення комплексного лікування. 